\title{
A Study among Community Living Underneath SUTET about The General Health Condition and The Electromagnetic Fields Exposures
}

\author{
Corrie Wawolumaya," Djoko Darwanto***
}

\begin{abstract}
SUTET or the Extra High Voltage Transmission Line of $500 \mathrm{kV}$ has passed through larger residential areas in the community. The aim of study is to provide the description of general health condition of community residing under SUTET in the urban poor of Jakarta and surrounding. The design of study was cross sectional, carried out among 1200 respondents which were taken stratified proportional purposively, based on zones of the electromagnetic field exposures. Data were collected through observation, interview and physical examination. The electric field and the magnetic field exposures were separately measured outside and inside the houses. The highest electromagnetic field exposures were measured at one meter height above the ground , for the electric field 3,1 $\mathrm{kV} / \mathrm{m}$. and the magnetic field $550 \mathrm{~mA} / \mathrm{m}$ or $687,5.10-3 \mu \mathrm{T}$, were identified in zone $10-20 \mathrm{~ms}$. The magnetic field was decreasing gradually through zone $2300 \mathrm{~mA} / \mathrm{m}$ and nearing zero in zone 3. Both the highest electric field and the magnetic field exposures were below the threshold values stated by SNI 2003 , $5 \mathrm{kV} / \mathrm{m}$ dan $0,1 \mathrm{mT}$ or $80.104 \mathrm{~mA} / \mathrm{m}$ (note: $1 \mathrm{~A} / \mathrm{m}=1,25 \mu \mathrm{T}$ ). The highest electric field exposure was identified at one meter height from the ground $2,5 \mathrm{kV} / \mathrm{m}$ at 02.00-03.00 hours a.m and the highest magnetic field $2400 \mathrm{~mA} / \mathrm{m}$ at 12.00-16.00 hours p.m. The biggest portion of houses was poor ( $30 \%$ ) were being housed for morethan 30 years. The major diseases were found similar in all zones i.e., dental diseases, myopia and hypertension.
\end{abstract}

Key words : SUTET, zones, physical examination, 10 major diseases.

\begin{abstract}
Abstrak
Jaringan SUTET Perusahaan Listrik Negara banyak melalui daerah pemukiman. Tujuan penelitian mendapatkan gambaran kesehatan penduduk yang bermukim di bawah SUTET dan di daerah urban miskin Jakarta dan sekitarnya. Penelitian disain kroseksional ini dilakukan pada sample 1200 kepala keluarga yang ditarik secara stratifikasi proportional purposif berdasarkan zona kuat medan elektromagnet. Data dikumpulkan dengan metoda observasi, wawancara dan pemeriksaan kesehatan. Kuat medan listrik dan medan magnet diukur terpisah di luar rumah, dan di dalam rumah. Ditemukan kuat medan listrik tertinggi

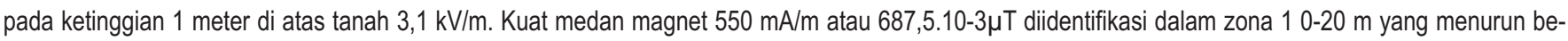
rangsur pada zona $2300 \mathrm{~mA} / \mathrm{m}$ dan mendekati 0 pada zona 3. Medan listrik dan medan magnet berada di bawah nilai ambang SNI 2003, $5 \mathrm{kV} / \mathrm{m}$ dan $0,1 \mathrm{mT}$ atau $80.104 \mathrm{~mA} / \mathrm{m}$ (note: $1 \mathrm{~A} / \mathrm{m}=1,25 \mu \mathrm{T}$ ). Medan listrik tertinggi ditemukan pada ketinggian 1 meter dari tanah 2,5 kV/m pada jam 02.00-03.00 pagi dan medan magnet ttinggi $2400 \mathrm{~mA} / \mathrm{m}$ pada jam 12.00-16.00.Jenis rumah terbanyak adalah rumah kumuh ( $30 \%$ telah dimukimi lebih 30 tahun. Penyakit utama di semua zona adalah gangguan gigi geligi, myopia dan hipertensi yang tidak berbeda antara zona.
\end{abstract}

Kata kunci : SUTET, zona, kondisi kesehatan, 10 penyakit utama. 
SUTET or the Extra High Voltage Transmission Line $500 \mathrm{kV}$ has been used for transportation of the electric energy from the Power Plant Source through transmission line to the consumers in the community. In the next few years the expansion of establishment of SUTET network in Indonesia will cover larger areas of people residence nevertheless the program has to be carried out due the escalating need of power for industrial as well as domestic. In big cities the populations are increasing while the price of lands are skyrocketing, consequently the power lines have to go through people residence, or more people come and reside underneath.

Better and accurate information are needed to help people living underneath for feeling safely, readily to cope with the environment as well as for the government to formulate appropriate policies and programs for this specific segment of population. The study was aimed to provide the descriptions on the general health which was measured by the 10 (ten) major diseases/disorders identified, the electromagnetic fields exposures and the related factors among population living underneath SUTET in the urban poor of Jakarta and Tambun.

\section{Method}

The design of study was cross sectional, about 1200 respondents (the calculated sample size was 753) were participated in the study. Samples were collected based on stratification by region/city, sub districts and hamlets while the unit of cluster was a household (HH). Respondents were heads of household and the recruitments were stratified proportional based on zones. The inclusion criteria was people who have been living underneath SUTET and were ready to participate in the study. Informed consents were agreed by the heads of household. Data were collected based on zones while zones were stated based on Djoko's measurements in his study result, 1996, stating the highest power of electromagnetic field found in zone $1,0-30 \mathrm{~ms}$ away from the zero point of midspan, decreasing in zone $2,30-70 \mathrm{~ms}$ and nearly zero at zona $3,70-100 \mathrm{~ms}^{1}$

The methods of data collections were by observations, interviews with questionaires as well as physical examinations. Socio-demographic data (age, education), socioeconomic (income) and duration of stay at the location. Medical doctors did the diagnosing of physical health, the identification of 10 major diseases. The electromagnetic fields i.e., the electric field and the magnetic field were measured separately using the Electromagnetic Field Intensity meter, Holaday apparatus. ${ }^{2}$ The measurement of the electromagnetic field were carried out inside and outside the house. Data were analyzed descriptively as well as analytically based on zones.

The measurement of the electromagnetic field were carried out in several groups as follows: (1) lateral measurement from the zero point/midspan $(0 \mathrm{~m})$, (2) measurement at the open field during 24 hours, (3) measurement inside the house, (4) measurement outside the house. The measurements inside and outside the house were carried out in two conditions i.e., the electricity was on and out, being measured in the morning hours, mid day and night. These concepts of measurements were based on the assumption that in the morning, the air humidity is high, in the midday the electricity used is low, the humidity is low, and at night, the peak of burden with high humidity.

\section{Results \\ The Study Location}

The measurement of the electromagnetic exposures had been carried out based on the socio-demograhic sampling frame developed underneath SUTET. The location was stratified into three zones, zone 1, zone 2 and zone 3. The demographic data were collected based on zones which located underneath SUTET, coded based on region, subdistrict and hamlet. The coding was based on location of tower in the hamlet, subdistrict and region. The number of head of households participated was 571 households in five hamlets, as follows :

\section{Lateral Measurements from The Zero Point}

This measurement aimed to identify the electric and magnetic field power as a function of distance which had been used as reference to state the zones. Djoko, showed his lateral measurements with the highest electric field between 0-30 meters, went down from 30-70 meters and becoming very small at 70-100 meters. ${ }^{1}$

The lateral measurement from the 0 point of midspan considered the distance from the zero point of midspan, humidity $(66 \%-80 \%)$, temperature $\left(31,2^{0} \mathrm{C}-32,4^{\circ} \mathrm{C}\right)$ as well location of measurement based on distance from the ground (one and two meters height). The electric field curve measurements from the zero point of midspan (Look Picture 1).

Picture 1 The two curves showed similarity in the trend of reporting the highest power at the very near distance, zone 1, straightly under the tower, decreasingly being farther in zone 2 and becoming very small, almost zero at the distance about a 100 meter from the zero point of midspan. The curves were skewed to the right, showed the highest power identified at $10-20 \mathrm{~m}$ from the zero point, for $1 \mathrm{~m}$ high $3,1 \mathrm{kV} / \mathrm{m}, 2 \mathrm{~m}$ high $8,1 \mathrm{kV} / \mathrm{m}$. The power was decreasing at $70 \mathrm{~m}$ for $1 \mathrm{~m}$ high $<0,5$ $\mathrm{kV} / \mathrm{m}, 2 \mathrm{~m}$ high $<2 \mathrm{kV} / \mathrm{m}$ and becoming small at $100 \mathrm{~m}$, for $1 \mathrm{~m}$ high $0 \mathrm{~V} / \mathrm{m}, 2 \mathrm{~m}$ high very small almost zero $\mathrm{V} / \mathrm{m}$. Away from the distance of a $100 \mathrm{~m}$ both curves showed similar pattern overlapped paralelly with the power of zero $\mathrm{V} / \mathrm{m}$.

The electric field from power lines have little ability to 


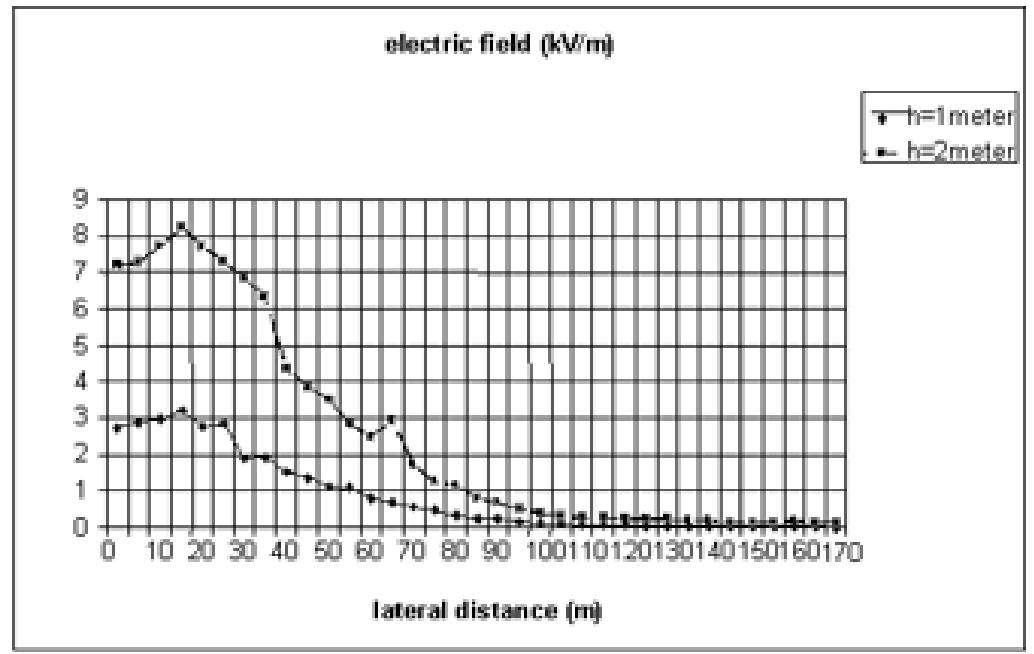

Picture 1. The Lateral Midspan Electric Field Curve (kV/m)

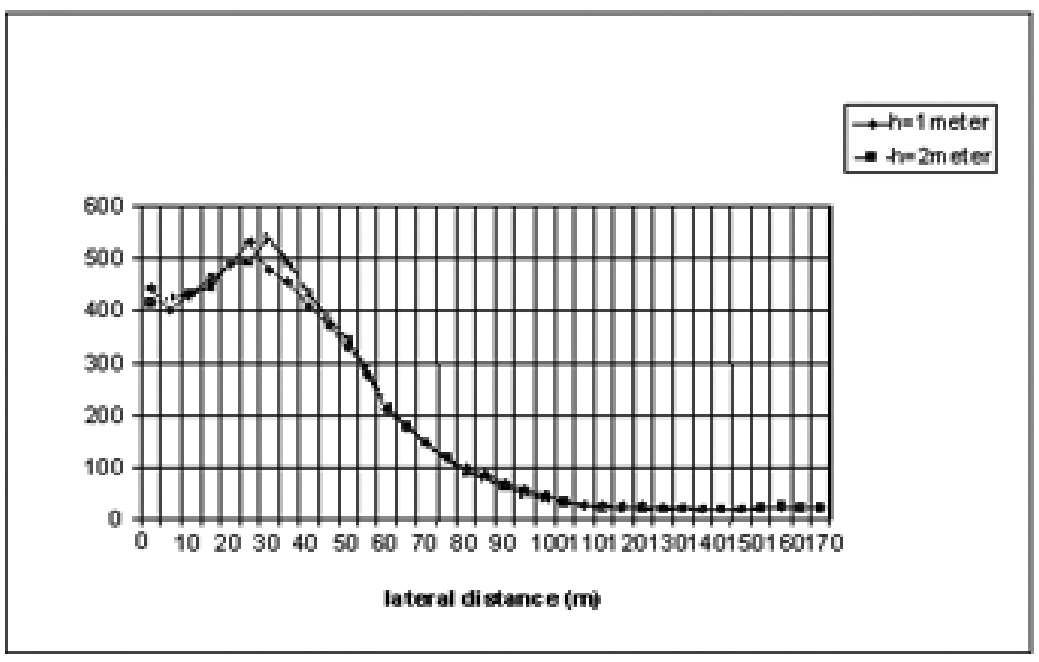

Picture 2. The Lateral Midspan Magnetic Field Curve

penetrate buildings as well as skin or human body (the shield effect). While the magnetic field associates with the power line frequency sources which exist only while current is flowing are difficult to shield, easily penetrates the building and skin. This the reason of the assumption that the biological effects from residential exposure must due to the magnetic component. ${ }^{5}$ Further study stated that power frequency magnetic field can exert forces on cellular structires but since biological materials are largely non magnetic, these power are usually very weak. ${ }^{6}$

Another measurement in Indonesia by UGM (Gajah Mada University), Yogyakarta, 1997-2005 underneath the network ranged from $3,32-4,78 \mathrm{kV} / \mathrm{m}^{7}$

The magnetic field curves measured from the zero point of midspan (Look Picture 2). Picture 2, the mag- netic field curves also showed similar results as the electric field, skewed to the right curves in which the highest power were identified between $30-40 \mathrm{~m}, 550 \mathrm{~mA} / \mathrm{m}$ or $687,5 \cdot 10^{-3} \mu \mathrm{T}$ at 1 meter and two ms high. The magnetic field was getting smaller at $70 \mathrm{~m}$, kept on decreasing, becoming about $100 \mathrm{~mA} / \mathrm{m}\left(125 \times 10^{-3} \mu \mathrm{T}\right)$ and at 100 $\mathrm{m}$ were small nearly zero $\mathrm{mA} / \mathrm{m}$. This result were also similar to Djoko's findings, 1996. The highest magnetic field power in zone 1 was still below the SNI, $0,1 \mathrm{mT}$. $\mathrm{KLH}$ reported that the measurement of the magnetic field carried out by UGM ranged from 1,8 $-2,1 \mu \mathrm{T} .^{8}$

\section{Measurements Outside The House}

The aim was to provide the electromagnetic power data due the power line exposure considering the envi- 


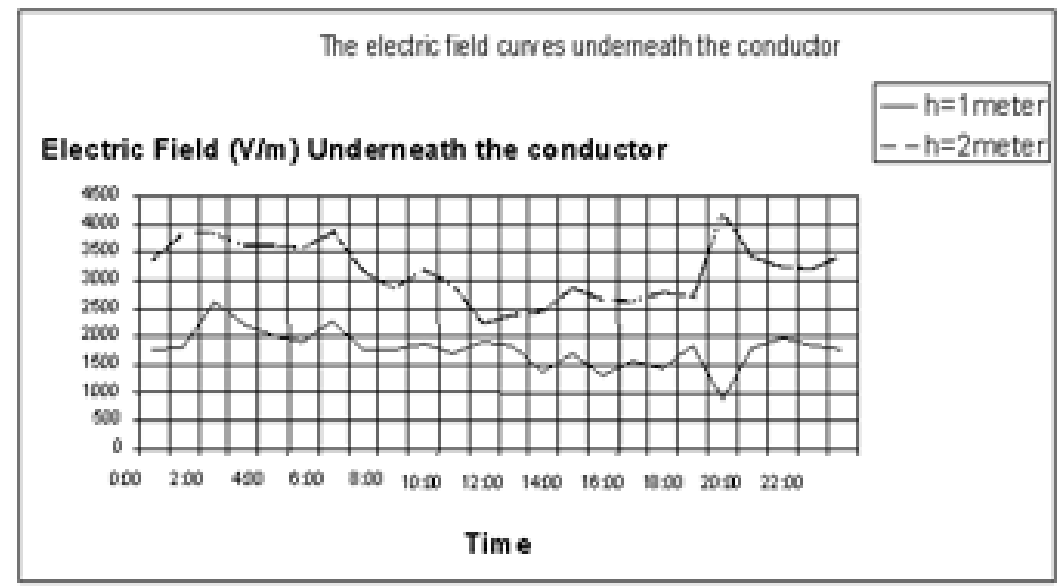

Picture 3. The Outside Electric Field Curve (Straightly Underneath The Conductor) (V/m)

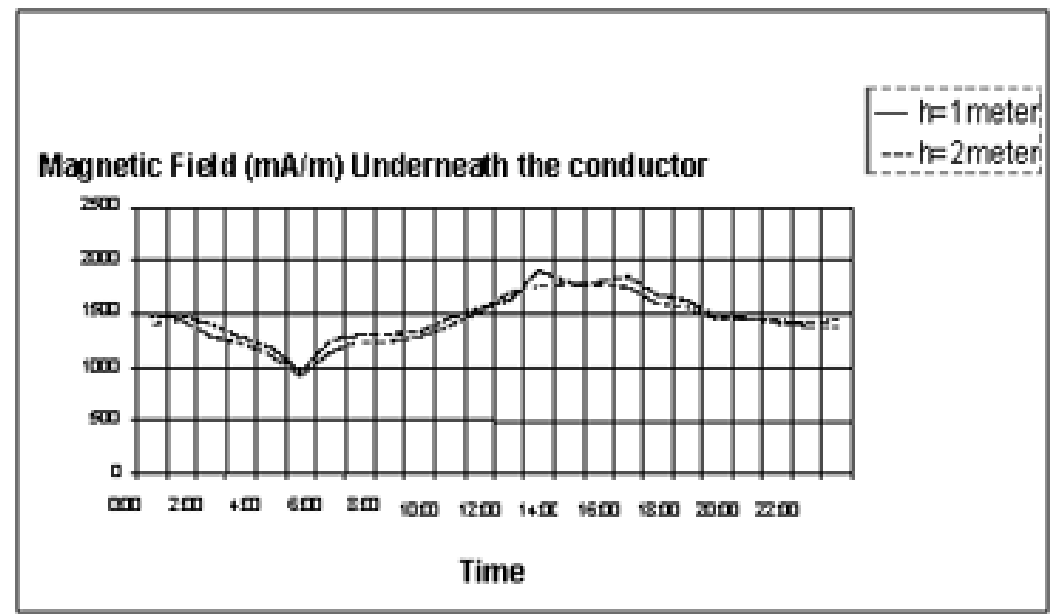

Picture 4. The Magnetic Field Curves (mA/m), Straightly Underneath The Conductor

ronmental factors i.e., shielding and distance from the power line. The measurement was carried out at the open field within 24 hours (underneath the conductor) (Look Picture 3).

Picture 3, showed the lowest electric field power was about $1009 \mathrm{~V} / \mathrm{m}$, between 18.00-20.00 o'clock, the highest power was between 02.00 and 03.00 o'clock in the morning hour about $2,5 \mathrm{kV} / \mathrm{m}$ at 1 meter high, at 2 $\mathrm{m}$ high, the lowest was about $2300 \mathrm{~V} / \mathrm{m}$ between 10.00 - 12.00 o'clock, the highest between 19.00 and 20.00 o'clock about $4 \mathrm{kV} / \mathrm{m}$. The findings of Djoko's reported at $1,5 \mathrm{~m}$ the highest between $03.00-07.00$ o'clock about $5 \mathrm{kV} / \mathrm{m}$, the lowest between $07.00-20.00$ o'clock, about $3 \mathrm{kV} / \mathrm{m}$. Djoko had used the same equipment at the same location in 1996 and 2006, nevertheless data showed that the power in 2006 was decreasing. The magnetic field curves underneath the conductor (Look Picture 4).

The measurements were carried out within 24 hours with the interval of 2 hours. The results of magnetic field at $2 \mathrm{~m}$ high, the highest between 13.00-14.00 o'clock, about $2000 \mathrm{~mA} / \mathrm{m}$ or $2,5.10^{-3} \mu \mathrm{T}$, while at 1 meter high, the peak measured was less than $1600 \mathrm{~mA} / \mathrm{m}$ between 12.00-16.00 o'clock. Djoko's findings, 1996 reported the magnetic field measured at $1,5 \mathrm{~m}$ high, the peak was at 9.00 o'clock, about $4,5 \mathrm{mG}(0,45 \mu \mathrm{T})$ while at $3 \mathrm{~m}$ high between 19.00-20.00 o'clock time 4,35 mG (0,435 $\mu \mathrm{T})$. The magnetic fields were slowing down, due to the condition of the power lines. The power lines decrease is a function of wire age and dust particles along the wires.

In the analyses study of power frequency field in an elementary school building in Spain identified the median level of magnetic field was $0,012 \mu \mathrm{T}$ and the highest $0,88 \mu \mathrm{T}$. In playground the magnetic field median level was $0,0095 \mu \mathrm{T}$, maximum $0,48 \mu \mathrm{T}$. The urban environment between 0,04-0,11 $\mu \mathrm{T} \cdot{ }^{8} \mathrm{UGM}$ reported that the measurement of the magnetic field ranged from 


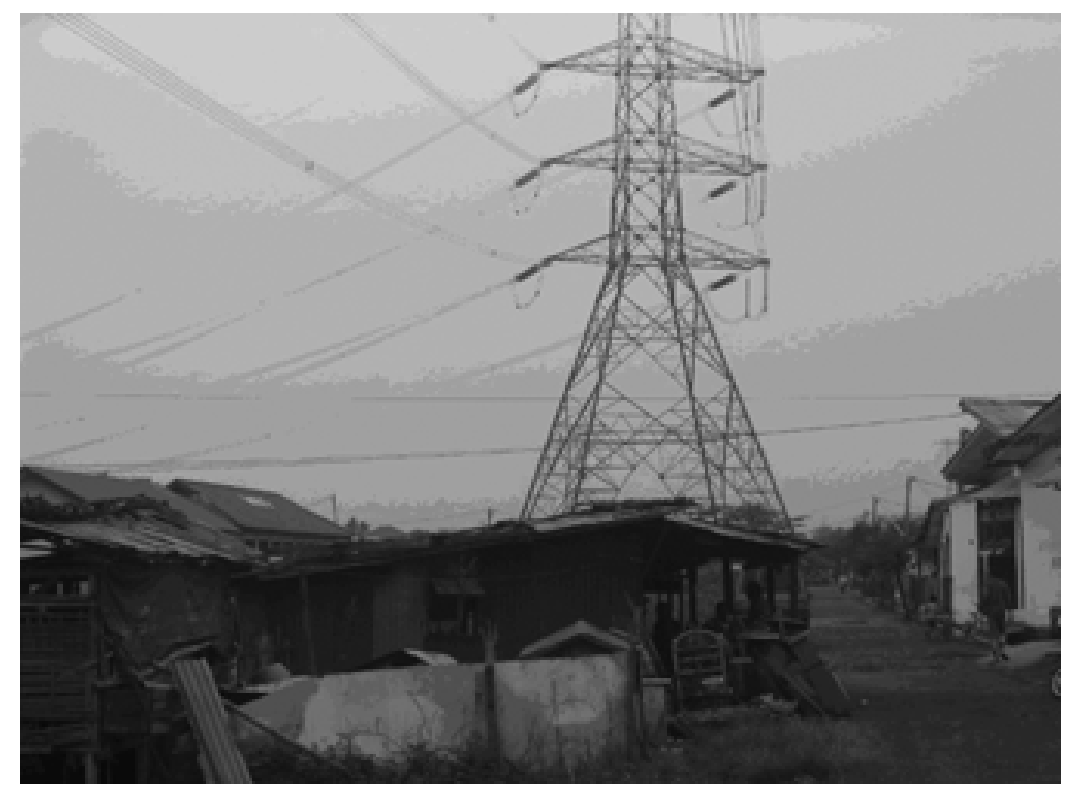

Picture 5. Types of Houses Underneath SUTET

\section{$1,8-2,1 \mu \mathrm{T} .^{9}$}

\section{The In-House Measurements}

The in-house measurement was aimed to identify the electromagnetic field exposures inside the house due to power line as well as domestic appliances and house wire electric system. This is to provide the description of dose being exposed to human body inside the house. The measurements inside the house were carried out in two conditions i.e., the electricity was on and out, measured in the morning hours, midday and at night time. These concept of measurement was based on the assumption that in the morning, the air humidity is high, in the midday, the electricity used is low, the humidity is low and at night time, the peak of power burden with high humidity.

The mode of the electric field inside and outside the house were $179,10 \mathrm{~V} / \mathrm{m}$ and $3,837 \mathrm{kV} / \mathrm{m}$, both were still less than the threshold value SUTET electromagnetic exposure for SUTT/SUTET, SNI 2003, $5 \mathrm{kV} / \mathrm{m} .{ }^{4}$ The highest magnetic field were also both inside and outside the house in zone $113,86 \times 10^{-2} \mathrm{mT}$ and 2,99 x $10^{-3} \mathrm{mT}$, both were less than SNI 0,1 mT. 4

\section{Types of Houses}

There were three types of houses observed, the very poor, poor and fair. The houses had similar kinds of roofs as well as walls. Most of roofs are thick tiles and asbestos while walls were from concrete bricks. Roofs and walls were factors to be considered which could influence the electric field inside the house. Also the pictures showed how poor the population was with such houses. Poor building were observed from $96,32 \%$ of poor building and only 3,64\% were permanent, the rest were semi permanent and poor building while most of the poor houses were observed in zone 1 and 2 (Look Picture 5).

\section{The Ten Major Diseases}

The physical examination identified among three zones as the three major diseases were dental, myopia, and hypertension followed by tonsillitis, ulcus pepticus, low body weight, lung diseases and high cholesterol. These patterns of diseases were found almost similar among the three zones.

At the same time it was reported in the sub district community health center (puskesmas) Pulo Gadung, East Jakarta the 10 major diseases as followed: acute upper tract infections, other respiratory disorders, dermatitis, allergy, diarrhea, dental disorders, pulpa, hypertension, and periodontal, ginggivitis and other dental problems (Look Table 1). ${ }^{10}$

\section{Discussions}

These findings were very important to answer the popular question continuosly posed by people individually and community about the safe distance area living surrounding SUTET. The big question was how far is the distance from SUTET for people to live healthly without being worry to suffer from diseases or disorders due to the impact of SUTET's electromagnetic exposure.

The Gordon theory of ecology or the Epidemiologic Triad mentioned that a problem of health will occur if 
Table 1. Distribution of Respondents Based on 10 Major Diseases by Zone

\begin{tabular}{lll}
\hline Zone 1 & Zone 2 & Zone $\mathbf{3}$ \\
\hline Dental & Dental & Dental \\
Myopia & Myopia & Myopia \\
Hypertension & Hypertension & Hypertension \\
Tonsillitis & Obesity & Ulcus pepticus \\
Ulcus pepticus & Ulcus pepticus & Obesity \\
Low body weight & Tonsilitis & Tonsilitis \\
Lung disorders & Lung disorders & Hypotension \\
Hypotension & Low body weight & Low body weight \\
Asthma & Sinusitis & Sinusitis \\
High cholesterol & High cholesterol & High cholesterol \\
\hline
\end{tabular}

there is an unbalanced condition happened among the three aspects, the agent, host (men) and the environment. ${ }^{3}$ No hazard will occur to human being if the agent or the exposure is still below the threshold value stated for normal exposure of agent.

The highest electric field exposure at zone $1(0-30 \mathrm{~m})$ ranged between $2,9 \mathrm{kV} / \mathrm{m}<3,15 \mathrm{kV} / \mathrm{m}$, the highest electric field was $3,1 \mathrm{kV} / \mathrm{m}$ showed that the electric field power was still under the normal threshold value of the National Standard of Indonesia/SNI , 2003 for SUTET. The normal threshold value of SNI for the electric field $5 \mathrm{kV} / \mathrm{m}$; the magnetic field $0,1 \mathrm{mT}$. ${ }^{4}$

Secondly the curves proved that the farther from the tower the saver people to live until the distance of a 100 $\mathrm{m}$ there will be no electric field exist anymore, while in zone 3,70 $-100 \mathrm{~m}$ ranging from $500 \mathrm{~V} / \mathrm{m}-0 \mathrm{~V} / \mathrm{m}$, the electric power were very low. These results of measurements were similar to Djoko 's finding, 1996 which were measured at the same location. ${ }^{1}$

As mentioned before, the Gordon theory, the magnitude of the magnetic field was important to assume whether there will be hazardous effect in human or not. Since the magnetic field was still below the SNI value, $0,1 \mathrm{mT}$ then the SUTET magnetic field is still safe for people living 0-100 $\mathrm{m}$ away from the midspan.

The magnetic field associates with the power line frequency sources which exists only while current is flowing is difficult to shield easily penetrates the building and skin. And this is the reason why the biological effects from residential exposure assumed was due to the magnetic component. ${ }^{5}$ Based on these findings, both the electric and magnetic field curves measured, several consequences can be stated as follows: (1) The electromagnetic power measured from 0 point at midspan through the three zones were smaller than the thresholds of SNI 2003. So for only direct negative health effects those areas are save. The savest place to avoid SUTET electro magnetic power is to live a 100 meter away from the midspan of tower. (2) The farther from the tower the saver the living place, at zone 3 both electric and mag- netic field were decreasing very low nearing zero. (3) In this study, the third zone $70-100$ meters was considered as the control zone since the samples collected were living between 0-100 meters away from the towers.

According to Djoko's, the inside house with thick tile and concrete bricks walls, the highest electric field was $10,81 \mathrm{~V} / \mathrm{m}$ and magnetic field $5,16 \mathrm{mG}(0,516 \mu \mathrm{T})$, houses with asbestos roofs and concrete bricks walls, the electric field $=8,89 \mathrm{~V} / \mathrm{m}$, the magnetic field 1,45 $\mathrm{mG}(0,145 \mu \mathrm{T})$. Looking at the inside house data in Table 1, the results both electric and magnetic field were larger than Djoko, but still lower the SNI threshold values. The bigger values could due to humidity as well as the dirty condition of wires and the electronic equipments inside.

Also about the outside house, Djoko, study results which located at the same area, reported the highest electric field was $199 \mathrm{~V} / \mathrm{m}$, the magnetic field $4,5 \mathrm{mG}(0,45$ $\mu \mathrm{T})$, both were less than study results in Table 1, below the SNI threshold values. Considering the electric field in zone $13,827 \mathrm{kV} / \mathrm{m}$, the recommendation is to hold the regular monitoring of the electromagnetic field, at the yards outside the houses underneath SUTET.

The diseases identified among people living in the three zones were relatively different from the diseases reported from the community health center visitors, since the respondents of study were assumingly healthy people, they were not health center visitors. In other words, the major diseases identified were disorders which were not considered acute by the public. Another research on myopia among the elementary school students in Jakarta pursued by medical students reported that about $30 \%$ of the students suffered from myopia but they did not consider myopia as a disease, so they do not complain to their parents. The adults with myopias acted the same as the students, when the myopia worsened then they see the doctors. ${ }^{11}$

Hypertension is the third major disease, has been reported as the degerative disease which has taken place as one of the major disease among urban population in Jakarta. ${ }^{12}$ Hypertension was also being reported not related to the exposure of the electromagnetic field in Jakarta. ${ }^{13}$ Ulcus pepticus also has been reported as slowly but sure becoming member of the 10 major diseases in Jakarta which was assumed to some extend being related to mental emotional disorders. Wawolumaya reported in her study at the same location of study, that mental emotional disorders was not related to the electromagnetic exposures. ${ }^{14}$ High cholesterol was the phenomenal symptom of urban population unbalanced fat diet which was the risk factor of the degerative diseases. ${ }^{15}$

The pathogenesis of the electromagnetic health impact in human body cannot be stated by one department of study alone. Repacholi, WHO, in his mosaic picture 
Researh Evaluation, Balanced of Studies Needed tries to answer the question: Does the Electromagnetic Exposure Cause Disease? Put different types of studies in a mosaic, consists of animal studies, cellular studies, epidemiological studies and clinical studies. ${ }^{16}$ WHO has to deal with that question and until now WHO has issued many information based on scientific researches gathering from the whole world collaborating with varies prestigious international agents of researches centers. The main function of the local epidemiological studies is to provide scientific health problems of population residing underneath ELF or Powerline $(50-60 \mathrm{~Hz})$ as well as to assist the government for good policy in relation with the powerline exposure.

The Environmental Health Criteria No. 238 from WHO issued in 2007 stated that following a standard health risk assessment process, it was concluded that there were no substantive health issues related to ELF (Extremely Low Frequency, $>0 \mathrm{~Hz}-100 \mathrm{kHz}$ ) electric fields at levels generally encountered by members of public. The magnetic field was the problem, but at high experimentally induced field strength above $100 \mu \mathrm{T}$, which cause nerve and muscle stimulation. ${ }^{17}$

The epidemiological studies with regards to longterm effects indicating an association between ELF exposure above approximately $0,3-0,4 \mu \mathrm{T}$ and an increase of childhood leukaemia. For this WHO asks to carry out researches in laboratory to identify the causal relationship. Until now, WHO still adopts the International Agency for Research on Cancer (IARC) statement that the magnetic field exposure is categorized as 'possibly carcinogenic' similar agents are drinking coffee, consuming pickled vegetables, exposed to gasoline engine exhaust. For epidemiological studies WHO asked, should not focusing only in cancer endpoint, but the chronic diseases such as neurodegenerative diseases, sleeping disturbance. ${ }^{18}$

Wawolumaya reported in her epidemiological study at the same location of study that no significant relationship identified between the electromagnetic field exposure and several diseases i.e., respiratory disease, heart disturbance, bone growth impairment and sleeping disturbance. ${ }^{19}$

The measurements of the electromagnetic field based on zones showed that the farther laterally distance from the midspan the smaller the power. At $>70 \mathrm{~m}$ the power both electric and magnetic were very small. Looking at the curve both were nearly zero at $100 \mathrm{~m}$. This is to show that distance from the midspan at about $>70 \mathrm{~m}$ as the agent of exposure is very small to hazard human being since the SNI for electric field is $5 \mathrm{kV} / \mathrm{m}$, magnetic field 0,1 mT. Djoko, at the same study location did the same measurements found similar findings. Considering the Epidemiologic Triad, the Ecological Theory of the Occurrence of Disease, saying a disease will occur if there is the unbalanced condition happening among the three elements i.e., the agent, host and environment. If the agent/exposure measured is still below the threshold value than no hazard will happen to human being.

This theory confirmed the farther people lived from the misdspan laterally the smaller the hazardous condition may occur directly to human being and being $>70$ ms from the midspan, very small impact nearly zero happen due to SUTET's exposure. Looking at the findings of health parameters among zones, several important aspects were to discuss. Firstly from the health aspect: data showed that health conditions were found no difference among zones. The same condition also showed by the ten major diseases identified among zones. The three zones reported similar pattern of diseases. These data also confirmed the technical aspect evidence of the measuring the electromagnetic field exposures and the Triad Epidemiologic theory.

\section{Conclusions}

There were several findings which were quite important according to the objectives of study as follows. (1) The eletric field curves showed the highest power of the electric field identified from the zero point, at 1 meter high $3,1 \mathrm{kV} / \mathrm{m}$, the power was decreasing at $70 \mathrm{~m}$ about $1 \mathrm{kV} / \mathrm{m}$ and becoming very small at $100 \mathrm{~m}$, almost zero $\mathrm{V} / \mathrm{m}$. The highest at zone one showed the electric field power was still under the normal threshold of SNI, 5 $\mathrm{kV} / \mathrm{m}$. (2) The magnetic field curves also showed similar results as the electric field skewed to the right curve in which the highest power were identified between 30-40 $\mathrm{m}, 550 \mathrm{~mA} / \mathrm{m}\left(687,5 \cdot 10^{-3} \mu \mathrm{T}\right)$ at 1 meter high, getting smaller at $70 \mathrm{~m}, 100 \mathrm{~mA} / \mathrm{m}\left(12510^{-3} \mu \mathrm{T}\right)$ and at $100 \mathrm{~m}$ were small nearly zero $\mathrm{mA} / \mathrm{m}$. (3) The elctric field curve outside house straightly underneath SUTET reported the highest was about $1009 \mathrm{~V} / \mathrm{m}$, between 18.00-20.00 o'clock, the highest electric field was between 02.00 and 03.00 o'clock in the morning hour about $2,5 \mathrm{kV} / \mathrm{m}$ at 1 meter high. (4) The power of magnetic field straightly measured underneath the conductor at $2 \mathrm{~m}$ high, the highest between 13.00-14.00 o'clock, about $2000 \mathrm{~mA} / \mathrm{m}$ $(2,5 \mu \mathrm{T})$ while at 1 meter high, the peak measured was less than $1600 \mathrm{~mA} / \mathrm{m}(2 \mu \mathrm{T})$ between 12.00 and 16.00 hours. (5) The ten major diseases showed no difference in pattern of disease among the three zones. The first three major diseases i.e., dental, myopia and hypertension. (6) The findings were to conclude the pattern of diseases in the control zone with very small electromagnetic exposures was not different compared with the pattern of diseases among the two zones with larger electromagnetic exposures since the values were all below the SNI threshold. People who living underneath SUTET 0$>70 \mathrm{~m}$ are safe from the direct negative health impact of SUTET's exposure. 


\section{Recommendation}

The highest electric field power measured at $10-20 \mathrm{~m}$ from the zero point of midspan for 1 meter high 3, 1 $\mathrm{kV} / \mathrm{m}, 2 \mathrm{~m}$ high $8,1 \mathrm{kV} / \mathrm{m}$. Needed regular monitoring of the electromagnetic field in zone 1, the magnetic field measured straightly under the conductor at 1 meter high, the peak was less than $1600 \mathrm{~mA} / \mathrm{m}(2 \mu \mathrm{T})$ between 12.00 and 16.00 o'clock. People should avoid standing under the conductor between 12.00 and 16.00 o'clock of the day. Considering the electric field in zone $1,3,827 \mathrm{kV} / \mathrm{m}$, the recommendation is to hold the regular monitoring of the electromagnetic field, at the yards outside the houses underneath SUTET.

\section{References}

1. Djoko D. Penelitian pengaruh medan listrik dan medan magnet saluran udara ekstra tegngan tinggi terhadap kesehtan manusia. Bandung: Aspek Teknik Lembaga Pelayanan Masyarakat ITB; 1996.

2. Holoday instrument for measuring the electromagnetic field. Holaday Industries, Inc., HI -3604. Elf survey meter, User Manual Holaday Ind., Inc, 1992

3. Beaglehole R, Bonita R, Kjellstrom T. The epidemiologic triad (in). Basic Epidemiology. Geneva: WHO; 1993.

4. Indonesian Nasional Standard on Electromagnetic Field; The threshold values of Sutet and SUTT, Indonesia, SNI 04-6950-2003.

5. Moulder JF. Power frequency fields an cancer. Crit Rev Biomed Eng: 1998. 26, pp 1-116.

6. King RWP. The interactin of power line electromagnetic field with the human body. IEEE Eng Med Biol. 1998: 67-78.

7. UGM. Pengukuran medan listrik 'Listrik -Sutet. Manfaat dan Kesehatan
' Lembaga Kerjasama Fakultas Tekik UGM Yogyakarta, 2007 , pp 43

8. Tardon A, Velarde. Exposure to extremely low frequency magnetic field among primary school children in Spain. J Epidemiol Community Health. 2002; 56: 432-3.

9. UGM. Pengukuran medan magnet. Listrik -Sutet, Manfaat dan Kesehatan. Yogyakarta: Lembaga Kerjasama Fakultas Teknik UGM; 2007. p. 43.

10. Laporan tahunan Puskesmas Kecamatan Pulo Gadung Jakarta Timur. 2006.

11. Penelitan prevalensi miopia pada siswa SD dan faktor faktor yang berhubungan pada siswa SD Jakarta Pusat [skripsi]. Jakarta: FKUI; 2006.

12. Wiweko A, Riyasa IG, Agastyo K, Racman D, Mona PI, Mardyansyah D, dkk. Prevalensi hipertensi dan faktor3 yang berhubungan pada anggota TNI AL Jakarta, 2007 [skripsi]. Jakarta: FKUI; 2007.

13. Wawolumaya C. A study on hypertension among population living underneath SUTET and its related factors Jakarta, 2009. Yogyakarta: BKM, FKUGM (24), 4. pp 163-217.

14. Wawolumaya C. A study on mental emotional disorders with Cornell Medical Index (CMI) Score among community living underneath SUTET 500 kV, 2008. Bulletin Health Studies. 2008; 36, 4: 156-67.

15. Bakti. Kadar cholesterol pada pekerja di perusahaan X dan faktor-faktor yang berhubungan, 2006 [tesis]. Jakarta: FKUI; 2007.

16. Repacholi MH. Project and result so far. WHO's International EMF. WHO: Geneva, Switzerland: 2006. Available from: www.who.int/emf/.

17. WHO. Human health impact of the electromagnetic exposure. Environmental Health Criteria (EHC) Monograph no 238. 2007, Juni. Available from: www.who.int/emf/.

18. Wawolumaya $\mathrm{C}$. The study on health impact of suteti among community living underneath Suteti towers. BKM. 2007; 23 (4): 155 - 212. 